\title{
日本脳炎ウイルスの抗原分析に関する研究
}

\author{
相沢主税吉岡勇雄 \\ 山岸郭 郎笠原四 郎
}

\section{ANTIGENIC ANALYSIS OF JAPANESE ENCEPHALITIS VIRUS BY CROSS NEUTRALIZATION TEST}

\author{
Chikara AIZAWA, Isao YOSHIOKA, Hiroo YAMAGISHI and Shiro KASAHARA \\ The Kitasato Institute
}

〔受付：12月 6 日，1967 年〕

\section{総括}

日本国内占上び国外（台湾・タイ）で分離された 10 株 の日本脳炎ウイルスの抗原分析索試み，家患初期免疫血 清を用いプラック減少法による交叉中和試験を行ない次 の成績を得た.

1）中山一予研・中山-薬検 ・Warren ・張の四株が 比較的近縁の 1 群意形成して居り，他方 JaGAr 01, Cheingmai の 2 株が互に近縁関係索もちながら且，相 良・林・HV 1 の 3 株が形作る1群と近接していること を認めた。しかし上記各群注一部に氺いて若干ずつ重複 して居り，隔絶した群を形成していなかった。

2）個々のウイル久株の内，中山一予研株は家兔初期 免疫血清中に中山一薬検株招よび Warren 株以外のウ イルス株汇対する中和抗体を，ごく小量しか旇生せしめ ないきわ好て特異なウイルス株で㐫つた。

以上，地理的条件飞上る型別法吻論，決定的な型别を 寸る穼でに到らなかった。

\section{緒晋}

日本脑炎ウイルスは長い間免疫学的には1種類である と考えられていた。しかしながらポリオやインフルエン

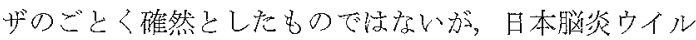
ス株間に抗原構造上可成りの差異のあることが認められ てきた。すなわち 1953 年 Hale がマラヤで分離した 6 株の日本脳炎ウイルスについての報告に端を発したさい つてよいであるう。 Hale 怯上記 6 株のウイルス拉よび 中山株ウイルスとで交叉補体結合反忘および交叉感染防 御試験を行ない，7株のウイルスが3つの型に分けら

北里研筲所
れることを示唆した（Hale \& Lee, 1954)，その後，感 染防御試験・血球凝集抑制試験等を用いて詳細任謂心゙た 報告が数々なされたが，型別をするまでに到らなかつた (小林，1959；緒方，1959)。奥野ら (1962) は吸収血清定 用いての血球凝集抑制試験により JaGAr 01 株ウイルス をもつて代表される1群と，I-58株ウイルスをもつて代 表される他の 1 群とに型別されることを登表し，日本 細炎ウイルスの型別に新たな資料を提示した（奥野ら， 1962).

日本脳炎ウイルス株の間にこのよらな抗原構造の差異 の岕ることが事実で亦るならば，中山一予研株をもつて 日本脳炎ウイルスの代表株として，日本脳炎のすべての 研究堂推進すること住危除なこととなるう。又予防衛生 上の種々の点においても，、ろいるな支障が执こること， が当然予測されるところである.

他方, Arbo ウイルスの中で東部アメリカ婜脳炎ウイ ルス (EEE) (Casals, 1964) および West Nile ウイル ス (WN) (Hamman et. al., 1965) 怯，そ北らのウイル スが分離された地理的臸異によって抗原構造が異ること が，血球凝集抑制圾験の成績から知られている。すなお ち北米で分離された EEE ウイルスと南米で分離された EEE ウイルスとでは 抗原構造に差異があり，又アフリ カ祘よび中近東地区で分離された WN ウイルスはイン ド地区で分離された WN ウイルスと秒々翼るといった 成續が報些されている。同様の試験孝日本脳炎ウイル久 について行なったところ， EEE ウイルスや WN ウイ ルスで認められたように，地理的条体により抗原構造に 差異のある成績注認文られなかった(Hanman \& Price, 1966).

われわれ性日本脳炎ウイルスの種々の株が果して抗原 
表 1 实験に用いた日本脳炎ウイルス株

\begin{tabular}{|c|c|c|c|c|c|c|}
\hline 名 & 分離年度 & 分離場所 & 分離材料 & $\begin{array}{l}\text { 分与老うけた時の材 } \\
\text { 料の継代レベル }\end{array}$ & \begin{tabular}{|l|} 
免疫に用いた忉料 \\
の分与後の継代数
\end{tabular} & 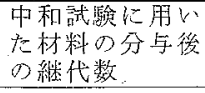 \\
\hline JaGAr 01 & 1959 & 群 馬 & コガタアカイエカ & BM-5, AM-2, BM-3 & BM-1 & $\mathrm{BM}-2$ \\
\hline$I$ 藤 & 1964 & 大 服 & ヒト脳 & $\mathrm{BM}-3$ & BM-1 & $\mathrm{BM}-1$ \\
\hline 相 良 & 1964 & 熊 本 & ブタ脳 & $\mathrm{PK} \cdot 21$ & BM-2 & BM-2 \\
\hline $\mathrm{HV} 1$ & 1958 & 台 湾 & ヒト脳 & $?$ & BM-1 & BM-1 \\
\hline 張 & 1965 & 台 湾 & ヒト脳 & BM-1 & $\mathrm{BM}-1$ & BM-1 \\
\hline 森 & 1965 & 台 溜 & ヒト脳 & BM-1 & BM-3 & $\mathrm{BM}-3$ \\
\hline Cheingmai & 1964 & タ 1 & ヒト脳 & $\mathrm{BM}-7$ & BM-1 & BM-1 \\
\hline 中山 (薬検) & 1935 & 東 京 & ヒト猆ズイ液 & G-101 & BM-1 & BM-1 \\
\hline 中山 (予研) & 1935 & "l & 11 & $Y \cdot 41$ & $\mathrm{BM}-2$ & BM-6 \\
\hline Warren & 1935 & $\prime \prime$ & $\prime \prime$ & CE-3, BM-5 & BM-1 & BM-1 \\
\hline
\end{tabular}

$\mathrm{BM}$ ：哺乳マウス, $\mathrm{PK}$ ：初代ブタ㹂細胞， $\mathrm{CE}$ ：䳕胚センイ芽細胞， $\mathrm{AM}$ ：成熟マウス

棈造上 2 群ないしは数群に大別され得るか否か，又その 場合に分離された地理的条件などが関与しているかどう かを調べるために，日本国内および国外で分離された 10 株のウイルスについて，組織培養法による交叉中和 試験によつて調べることを意図し以下の実験を行なつた のでその成績について述べる。

\section{材料と方法}

ウイルス株： 実験に使用したウイルス株は「表1」 に示された10株のものである。いずれも予研ウイルス 4 室より分与䘮う忛たもので，継代数を可及的に増加さ せ妨よう留意して実験に用いた。下三段の 3 株のウイル スはすベて 1935 年分離された中山株ウイルスが異る研 究機関に拉いて継代維持されたものである。

家忽免疫血清： 使用した家鬼住体重約 $2 \mathrm{~kg}$ のもの で，あら加し中山山一予研株ウイルスに対して中和抗体 陰性であること永たしかめたのち用いた，上記各ウイル 又株每に 2 5 羽の家鬼を使用して免疫血清を作製した。 免疫方法は前記継代レベルのウイルス感染マウス脳 10 \%乳剤の $10,000 \mathrm{rpm} 30$ 分間の遠心上清液の更に 10 倍 希积のウイルス液を脳内に $0.5 \mathrm{mI}$ ，腹脭内に $5.0 \mathrm{ml}$ ，皮 下に $1.0 \mathrm{ml}$, 静脈内に $5.0 \mathrm{ml}$ (中山-予研株・中山一薬検

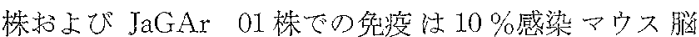
乳剂の遠心上清液で脳内㐨上び腹腔内接種のみ）を一眭 に接種し，接種後 1 週で一部採血をしこれを初期免㽷血 清とした. 初回接種後 2 週・3 週・4 週目に前記りイル ス感染マウス脳 $10 \%$ 乳剤の遠心上清液を静脈内に 2.0 $\mathrm{ml}$ 宛接種し，最終回の接種後 2 週目に採血子行ない， これを後期免疫血清とした。初期，後期の両免疫血清と も，各ウイルス株毎に $2 \sim 3$ 羽のものを夫々プールして 実験に供した。

鵎胚センイ芽細胞の単層培養：11日孵化卵の鶏胚を
トリプシンで型のごとく消化し， $75 \mathrm{~mm}$ 径シヤーレに 450 万個 $/ \mathrm{ml}$ の細胞浮遊液を $8 \mathrm{ml}$ 宛入れ, $\mathrm{CO}_{2}$ フラン 器で $20 \sim 24$ 時閒 $37^{\circ} \mathrm{C}$ 培養後のものを用いた。細胞浮. 遊液に用いた培養液は，ラクトアルブミン水解物 0.5 \%，コウシ血清（日本脳炎中和抗体陰性のもの）10\%， Earle 液 89.5 \%よりなるものである。

中和試験の術式(吉岡ら，1965)：ウイルスのみ接種

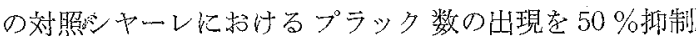
せしめるような血清希釈倍数を求めるために，0.55\% 牛血清アルブミン加 Hanks 液字用いて適当な数段階の 希勫血清孛作り，これに約 150〜300 Plaque Forming $\mathrm{Unit} / 0.4 \mathrm{ml}$ のウイルス液老等量加え $37^{\circ} \mathrm{C}$ に 60 分閒掠 レた後, ウイルス・希釈血清の混合液を培養シヤーレ1 枚あて $0.4 \mathrm{ml}$ 宛接種した。各混合液每に 2 枚のシヤー レを使用した。 ウイルスのみ接種の対照として，希䣋血 清の代りに0.55\%牛血清アルブミン加 Hanks 液と上記 ウイルス液との等量比混合液を $37^{\circ} \mathrm{CK} 60$ 分間抒いた後 を10枚のシャーレに接種した，接種されたシャーレは その $0.4 \mathrm{ml}$ すい゙て $\mathrm{CO}_{2}$ フラン器内に 90 分置き, ウイ ルス吸着を行なわした，その後，寒天加培地を $8 \mathrm{ml}$ 宛 各シャーレの細胞層に重層し，寒天の固まるのを待つて 寒天層を上にし， $\mathrm{CO}_{2}$ フラン器内で培養を行なつた。 第一次寒天加培地の混合前の組成は下記の通りで方。

A液 $3 \%$ 寒天液 (Special Agar, Noble, Difco)

$90.0 \mathrm{ml}$

B液 $10 \times$ Earle (重媅・フェノールレッドを除く)

$18.0 \mathrm{~m}$ !

$$
\begin{aligned}
& 5 \% \text { ラトアルブミン水解物 } 18.0 \\
& 5 \% \text { イーストレート } 1.8 \\
& 7.5 \% \mathrm{NaHCO}_{3} \quad 5.4
\end{aligned}
$$

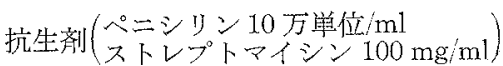


再蒸溜水

1.0

45.8

ウイルス接種後 2 日目に第二次寒天加培地 $4 \mathrm{ml}$ 宛の 重曙を行なつた。この寒天加培地の混合前の組成は下記 のごとくである.

A液 $3 \%$ 寒天液 (Special Agar, Noble, Difco)

$90.0 \mathrm{ml}$

B液 $10 \times$ Earle（重曹・フェノールレッドを除く） $18.0 \mathrm{ml}$

$\begin{array}{lr}0.1 \% \text { 中性赤 } & 8.0 \\ \text { 抗生訬 } & 1.0 \\ \text { 再蒸溜水 } & 63.0\end{array}$

第二次寒天加培地を重層した翌日にプラック数を計算 し，ウイルスのみの対照シヤーレに出たプラック数の 50 $\%$ の数々まで咸少せしめた希釈血清の希釈倍数を，50\% 前後のプラック数を示した希釈血清の倍数より比例で求 め，をれを中和抗体価としてあらわした。

\section{成 績}

一つのウイルス株を用いて作製された家象免疫血清 (プールされたもの)中に，そのウイルス株および他の 9 株のウイルスに対する中和抗体がどの位産生されている かを前述の中和試験の術式に従い測定してみた。

交叉中和試験の予備試験を初期および後期家兔免疫血 清を用いて実施したところ，後期免疫血清中には各ウイ ルス株に対する中和抗体価がずてて可成り近似した価を 示し, 後期免疫血清で洼各ウイルス株間に著明な差の表 われることを期待し難い成績を得た。したがつて本実験 に颃いては初期免疫血清を用いて行なつた交叉中和試験 の成績について述べる。

各ウイルス株に対する初期免疫血清中の中和抗体洒 恃，免疫に使用した抗原量が各ウイルス株間に可成りの
相異のあること江確かであり，且免疫に使用した家兔の 個体差もあるので，測定された中和抗体価の絶体值をも つて各ウイルス株を比較すること性妥当でない，よつて 免疫に用いられたウイルス株に対する中和抗体価を相対 中和抗体価 100 として表わし，他の 9 株に対する相効中 和抗体価を絶体值より比例で求めた. その成績が一括し て「表 2 」に示される。横の各段の数値が，夫夕のウイル ス株で㷛疫された家鬼初期免疫血清中の10株のウイル スに刘する相対中和抗体亚を示したものである。例えば 表の一段目の JaGAr 01株ウイルスで免疫された家 鬼の初期免疫血清中には，工藤株に対古年和抗体は $\mathrm{JaGAr} 01$ 株に対する中和抗体よりも2.38 倍高く検 出されたので 238 と示し, HV 1 株に対する中和抗体忙 JaGAr 01 株に刘する斿の $1 / 5$ しか检出されなかつ たので 20 と示してある.

各ウイルス株の棝互の関係を見易くするために，この 表をグラフに畫き直してみると「図」のごとくになる. すなわち免疫に使用したウイルス株に対寸る中和抗体価 を $\log _{10} 0$ として「0」の所に位置ゔ，その左右に各 ウイルス株の位置つ计を夫々の中和抗体価によつて行な うと，図に示されるように各ウイルスのシンボルがおか れる. 中!山予研株ウイルスで免疫された管鬼の免疫血 清 (図中下より二段目) 学例にとると, 中山一予研株の シンボルは「0」の位置に㧍かれ，中山一薬検株に刘す る相対中和抗体洒住 2 より 102 であるので，このウイ ルス株も又「0」の位置にシンボルがおかれる。同血清 中の HV 1 株に対する相対中和抗体価は 9.9 で中山一予 䃤株に対するそれの10分の1に当るため「一0.1」の位 置に同株のシンボルがおかれ，相良株に対する相対中和 抗体佂俚中山一予研株のそれの 100 分の 1 なので「一 2.0」の位置にシンボルが㧍かれている。この図で「一 $0.6 」 と\lceil+0.6 」 の$ 所で各段に通して示された縦線は,

表 2 初期家兔免疫血清の相対中和抗体価

\begin{tabular}{|c|c|c|c|c|c|c|c|c|c|c|}
\hline 抗血清 & $\begin{array}{c}\mathrm{JaGAr} \\
01\end{array}$ & 工藤 & 相良 & HV 1 & 張 & 林 & Cheingmai & $\begin{array}{c}\text { 中山 } \\
\text { (濼㭲) }\end{array}$ & $\begin{array}{c}\text { 中山 } \\
\text { (予研) }\end{array}$ & Warren \\
\hline $\mathrm{JaGAr} \quad 01$ & 100 & $238^{\circ}$ & 28 & 20 & 28 & 15 & 25 & 215 & 65 & 70 \\
\hline 工 藤 & 18 & 100 & 29 & 12 & 250 & 21 & 76 & 540 & 121 & 7 \\
\hline 相 良 & 68 & 200 & 100 & 102 & 54 & 117 & 42 & 340 & 190 & 34 \\
\hline HV 1 & 45 & 400 & 58 & 100 & 159 & 38 & 100 & 235 & 247 & 65 \\
\hline 張 & 6.4 & 12 & 15 & 5.3 & 100 & 8.3 & 13 & 29 & 50 & 70 \\
\hline 林 & 13 & 215 & 88 & 151. & 537 & 100 & 268 & 634 & 202 & 124 \\
\hline Cheingmai & 96 & 71 & 32 & 18 & 38 & 35 & 100 & 167 & 91 & 18 \\
\hline 中山（薬検） & 8.6 & 43 & 4.4 & 4.8 & 69 & 6.9 & 26 & 100 & 41 & 38 \\
\hline 中山（予研） & 0.8 & 8.5 & 1 & 9.9 & 8.3 & 1.2 & 1.7 & 102 & 100 & 26 \\
\hline Warren & 39 & 23 & 88 & 160 & 307 & 71 & 23 & 103 & 160 & 100 \\
\hline
\end{tabular}




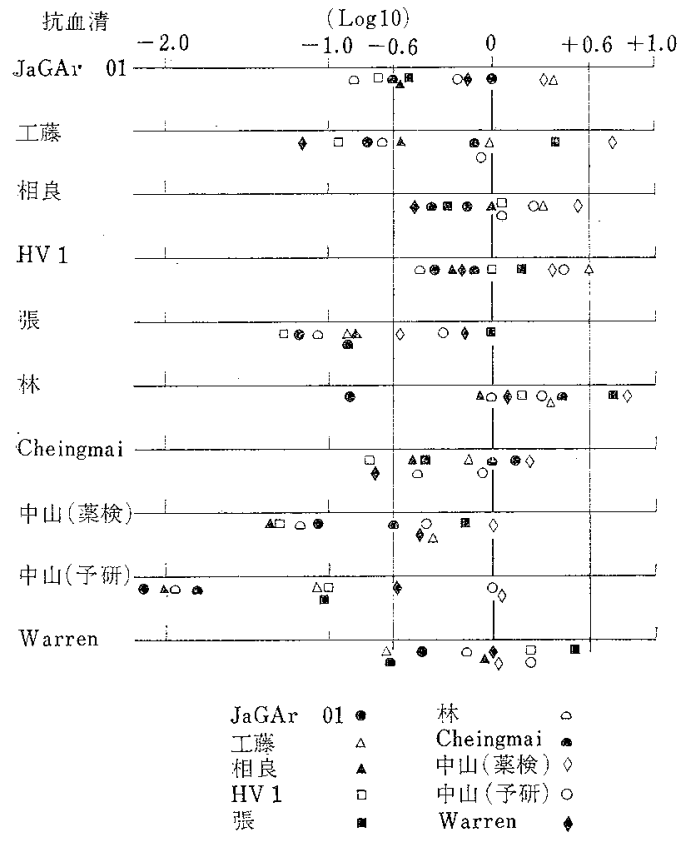

図 1 種々 JEウイルスに対する各家孯免疫 血清中の中和抗体

血清希釈や接種の際などにおこり得る実験誤差を考虑す るための線であることを示している。したがつて「一 0.6」の線より左方にシンボルが扔かれたウイルス株注, 免疫に使用したウイルス株に対して hetero であると考 えられる。

\section{考察}

われわれの実験の目的は，感染発症の防御機構に関運 の強そうに思われる中和抗体の状況を調べることによ り，抗原構造の差異の有無を究如るとに品つた。

われわれの得た成績より判断すると，図に於ける「一 $0.6 」 と 「+0.6 」 の$ 両線間からはずれたウイルス株の 内，特に「一0.6」の線上り左方に位䈯を占为るものは， 免疫に用いたウイルス株に対して hetero であると考光 てよいだろう。しかし確実に hetero であると云うため には，比較する 2 つのウイルス株が夫及相手の抗血清 で，共に hetero であることが必要となる。例をひいて 云えば，図に於いて抗 JaGAr 01 血清と抗林血清を 比べてみると，抗 JaGAr 01 血清で林株 ウイルスは hetero であり，抗林血清で JaGAr 01 株 ウイルスは hetero であるので，この雨者は hetero であると云えよ う。このようにして確実に hetero と云えるのは JaGAr 01-林の他に，Warren-工藤，Warren-Cheingmai があ る.
逆に「-0.6」と「+0.6」の両線内にあって homo と考允られるもの探してみると，相良一HV 1，相良一 林，HV1朴等々 20 組にも及占組合せが見出される。

実験に用いた 10 株のウイルスについて, homo, hetero の関係定図示しよらとするならば立体图要必要としよ う。これを簡単に云い表わすなら㳖，相良・林・HV 1 の 3 株江密接な関係を多つ1群をなし，中山一予研，中 山一薬檢・Warren・張の四株も比較的密接な関係をも つ1群を形成し，JaGAr 01株と Cheingmai 株の 2 株が近縁関係をもち乍ら相良・林・HV 1 株の 1 群纪比 較的近、関係にある. 工藤株法相良・林・HV 1 株の 1 群と中山一予研。中山一薬検株等汃作る1群との中間位 置している形である。そして上記 3 群も隔絶したもので なく，群の劣る株注他の群のある株と近縁関係をつこ とにより各群の一部が若干ずつ重なり合つて居る。

本実験に使用したウイルス株が僅か 10 株であるた为 に, 以上の上らな群別をもつて, 日本脳炎ウイルスの型 別とすることは绝険であるう。

韓・大谷ら (1967) 吅和試験化よる日本脑炎ウイルス の型别を陚み，JaGAr 01 型ウイルスと中山一预研型ウ イルス拉よび中䦕型ウイルスの存在することを示唆し， 尾崎ら (1967) 法中和 Kinetics 法による日本这炎少イル スの抗原分析を試み，JaGAr 01 叔よび中山一予研株ウ イルスが新鮮分離株との間に可なりの開きの亦ることを 認めてはいるが，両氏らも未だ決定的な型別をするまで には到っていない。

型別とは別に個々のウイルス株について考えるなら ば，中山一予研株が他の 9 株と比べて非常に特異なこと が図に一目瞭然となつている。すなわち中山一薬検株扔 よび Warren 株ウイルスに対する中和抗体はよく産生 しているが，他の 7 株に対してはごく少量の中和抗体し か産生していない，このことは中山一予研粎は他のウイ ルス株に比して，中和抗体産生能の点で非常に特異なウ イルス株であると云えよう。同じような傾向が，軽度で あるが中山一薬検株扔よび張株ウイルスについても認め られる。 これに反し，相良・HV1・Warren の3 株ウ イルスは他のウイルス株に対しても略々同じように中和 抗体を産生世しめていること注，別の意味で注目に值す ることである。すなわ広沉な抗体産生能法免疫原とし て有利な点をもつことになららし，ウイルス同定の際な どに他のウイルス株で作られた免疫血清よりもより有效 なものとなる可能性を持つている.

以上これまで得られた結果は，あくまでも家晒初期 免疫血清を用いて得られたもので岕り，一般諭として断 定するに消早であるかも知孔ない，日本脳炎当イルス の抗原分析はい方ば緒についたばかりであり，更により 
多くのウイルス株について調心゙ることの必要があると共 に，患者血清の面加らも抗原分析の緒口学求めることも 効果的な一方法となるう。この方面の研究は現在進行中 である。

本研究の一部洨文部省科学研究費によつた, 又本研究 の要旨注第 41 回日本伍染病学会総会（1967 年名古屋） に抒いて発表した。

\section{Summary}

Ten strains of Japanese encephalitis virus isolated in Japan, Taiwan and Thailand, were investigated by plaque reduction neutralization method.

Cross neutralization tests with rabbit earlyimmune sera demonstrated that all the viruses are divided into three groups. However, those three groups are not independent, but relativeclosely related each other.

Nakayama-NIH strain is closely related to Nakayama-Yakken and Warren strains which are sublines of Nakayama-NIH strain, but not related to other viruses.

Geographic variation in the antigenic character of Japanese encephalitis viruses was not observed by our cross neutralization tests.

\section{文献}

1) Casals, J. (1964). Antigenic variants of east. ern equine encephalitis virus. J. Exp. Med. 119, 547-565.

2) Hale, J. H. and Lee, L. H. (1954). A serological investigation of six encephalitis viruses isolated in Malaya. Brit. J. Exp. Path. 35,
426-433.

3) Hammam, H. M., Clarke, D. H. and Price, W. H. (1965). Antigenic variation of West Nile virus in relation to geography. Am. J. Epid. 82, 40-55.

4) Hamman, H. M. and Price, W. H. (1966). Further observations on geographic variation in the antigenic character of West Nile and Japanese B viruses. Am. J. Epid. 83, 113122.

5) Han, H. D., Oya, A. and Sakumoto, H. (1967). Studies on neutralization with Japanese encephalitis virus. III) Strain differences of Japanese encephalitis virus observed in neutralization. Japan. J. Med. Sci. Biol. (To be published.)

6) 小林一郎 $(1959) \div$ 日本脳炎ウイルスの 2 株の間 に存在す当免疫学的差異について。ウイルス 9 , 475-482.

7）緒方隆幸 (1959)。現行日本脳炎ワクチンの免㾳 効果心関する実験的砳究(第 2 報)。 ウイルス 9 , 124-129.

8）奥野剧，近藤昭，鈴木諴，伊東寿子 (1962)。日 本脳炎方イルスの血球凝集抑制反心故上び血球 凝集抑制抗体吸収試験に上る抗原分析一特に 1935 1960年䦎の分離 12 株間に見られる免檓 学的異同について、第10回日本ウイルス学会 総会講演.

9) Ozaki, Y. and Tabeyi, K. (1967). Studies on the neutralization of Japanese encephalitis virus. I. Application of kinetic neutralization to the measurement of the neutralizing potency of antiserum. J. Immunol. 98, 1218-1223.

10）吉岡勇雄，相沢主税，山岸郭郎 (1965). 日本檤 炎の中和試験方法について。日本伝染病学会雜 誌 39，201-205. 